\title{
Numerical model to simulate ventilation of dead-end mine working with brattice
}

\author{
Oleksii Voloshyn ${ }^{1}$, Mykola Biliaiev ${ }^{2, *}$, Viktoriia Biliaieva ${ }^{3}$, Vitalii Kozachyna $^{2}$, \\ Oleksandr Berlov", Tetyana Rusakova ${ }^{3}$, and Ivan Kalashnikov ${ }^{5}$ \\ ${ }^{1}$ Institute of Geotechnical Mechanics named by N. Poljakov of National Academy of Sciences of \\ Ukraine, 49005, Dnipro, Simferopilska Str., 2a, Ukraine \\ ${ }^{2}$ Dnipro National University of Railway Transport named after academician V. Lazaryan, 49010, \\ Dnipro, Lazaryan Str., 2, Ukraine \\ ${ }^{3}$ Oles Honchar Dnipro National University, 49010, Dnipro, Haharin Ave., 72, Ukraine \\ ${ }^{4}$ Prydniprovska state academy of civil engineering and architecture, 49600, Dnipro, Chernyshevsky \\ Str., 24a, Ukraine \\ ${ }^{5}$ Kharkiv Branch Office "Design and Research Institute of Railway Transport" of the Public Joint \\ Stock Company "Ukrainian Railway", 61052, Kharkiv, Kotliar Str., 7, Ukraine
}

\begin{abstract}
A computational model to simulate ventilation of a dead-end mine working with line brattice has been developed. To solve fluid dynamics problem, i.e. to compute flow pattern, model of inviscid flow has been used. That allows to compute quickly air flow pattern. To simulate dust dispersion in the dead-end mine working with brattice twodimensional equation of mass transfer has been used. Numerical integration of Laplas equation for the velocity potential has been carried out using Samarski two steps difference scheme of splitting. Proposed CFD model allows quick computing of dust dispersion in the dead-end mine working with brattice. Markers (porosity technique) have been used to create the complex geometrical form of computational domain. Results of numerical experiments which had been performed on the basis of the developed CFD model have been presented.
\end{abstract}

\section{Introduction}

Mining industry is an important branch in Ukraine. Among different scientific problems which are appeared in this branch, ventilation of dead-end mine working is among the most important [1-6]. Because of that, the dust pollution or chemical pollution in deadend mine working may be very serious and brings very negative consequences. Ventilation becomes the most important process of dust and others pollutant removal from dead-end mine workings. Experimental study of dead-end mine working ventilation takes much time and needs very expensive equipment. That is why mathematical modeling is a very important approach to study the problem. Mathematical simulation of dead-end mine working ventilation is a complicated problem. As a rule, solving this

*Corresponding author: diit.hydro.eco@gmail.com 
problem includes two steps. First of all, we must compute air velocity pattern in the deadend mine working. At the second step the process of pollutant dispersion under ventilation is computed. Worthy of note, that it is very important to compute correctly velocity flow in the dead-end mine working. It means that when we use numerical methods to solve fluid dynamic problem, we must compute velocity in each computational cell so that in each computational cell predicted components of air velocity satisfy equation of continuity. If not, we can obtain the computational cell with "fictitious source" or "fictitious drain". If such "fictitious sources" appear in the computational region they break all the process of numerical simulation and it is impossible to simulate pollutant dispersion at the second step of numerical experiment.

Also, for practice, it is important to have quick computing models to run many scenarios during one working day. Application of commercial codes, which are mostly based on Navier-Stokes equations, needs much computational time and these codes are very expensive. Also, it is necessary to use powerful computers to run these codes. Worthy of note that, scientific papers, which represent numerical simulations on the basis of commercial codes, sometimes, represent results of pressure or velocity patterns in dead-end mine workings and not concentration fields. Analysis of literature shows that in Ukraine there is an obvious deficit of mathematical models which can be used for analysis and estimation of dead-end mining ventilation efficiency.

The goal of this work is development of CFD model to compute ventilation process in dead-end mine working with brattice.

\section{Methods}

A CFD model which has been developed to compute dust dispersion in dead-end mine working with brattice is based on two governing equations: equation of potential flow and equation of pollutant dispersion. For the numerical integration of governing equations difference schemes are used.

\subsection{Theoretical part}

As it was said before, when we study problems of dust dispersion in mines, at first, it is necessary to compute air flow. When the air pattern has been computed we can simulate dust dispersion. To simulate air flow in dead-end mine working we used the model of potential flow $[7,8]$ :

$$
\frac{\partial^{2} P}{\partial x^{2}}+\frac{\partial^{2} P}{\partial y^{2}}=0
$$

where $P$ is velocity potential, $x, y$ are Cortesian coordinates, $\mathrm{m}$.

Velocity components are determined as

$$
u=\frac{\partial P}{\partial x}, v=\frac{\partial P}{\partial y} .
$$

Boundary conditions for (1) are [9]:

1) at the solid boundaries Neuman's condition is used: $\partial P / \partial n=0$, where $n$ is unit vector of external normal to the boundary;

2) at the inlet boundary Neuman's condition $\partial P / \partial n=V_{n}$ is used. Here, $V_{n}$ is known velocity, $\mathrm{m} / \mathrm{s}$; 
3) at the outlet boundary Dirichlet's condition is used: $P=P_{0}+$ const, where $P_{0}$ is an arbitrary number.

Process of pollutant dispersion in the region of interest is modeled on the basis of the following equation [8-11].

$$
\frac{\partial C}{\partial t}+\frac{\partial u C}{\partial x}+\frac{\partial v C}{\partial y}=\frac{\partial}{\partial x}\left(\mu_{x} \frac{\partial C}{\partial x}\right)+\frac{\partial}{\partial y}\left(\mu_{y} \frac{\partial C}{\partial y}\right)+\sum_{i} Q_{i} \delta\left(x-x_{i}\right) \delta\left(y-y_{i}\right)
$$

where $C$ is pollutant concentration, $\mathrm{kg} / \mathrm{m}^{3} ; Q_{i}$ is emission rate, $\mathrm{kg} / \mathrm{s} ; \delta\left(x-x_{i}\right) \delta\left(y-y_{i}\right)$ are Dirac's delta functions; $\mu_{x}, \mu_{y}$ are diffusion coefficients, $\mathrm{m}^{2} / \mathrm{s} ; u, v$ are velocity components, $\mathrm{m} / \mathrm{s} ;\left(x_{i}, y_{i}\right)$ are coordinates of emission, $\mathrm{m} ; t$ is time, $\mathrm{s}$.

Boundary conditions for (2) are discussed in [9]. We solve (2) with the initial condition $C=C_{0}$, where $C_{0}$ is known concentration of pollutant.

\subsection{Numerical model}

To solve numerically (1) we used Samarski's method. According to this numerical method, preliminary, (1) is written in the following form [7]:

$$
\frac{\partial P}{\partial t}=\frac{\partial^{2} P}{\partial x^{2}}+\frac{\partial^{2} P}{\partial y^{2}}
$$

where $t$ is fictitious time.

Solution of (3) for $t \rightarrow \infty$ approaches to the solution of equation (1). Before numerical integration of (3) it is necessary to set $P$ in the computational region at $t=0$. We use condition $P=0$ in the computational region at $t=0$. For numerical integration of (3) the following implicit scheme of splitting is used [12]:

$$
\begin{gathered}
\frac{P_{i, j}^{n+1 / 2}-P_{i, j}^{n}}{0.5 \Delta t}=\frac{P_{i+1, j}^{n}-P_{i, j}^{n}}{\Delta x^{2}}+\frac{-P_{i, j}^{n+1 / 2}+P_{i+1, j}^{n+1 / 2}}{\Delta x^{2}}+ \\
+\frac{P_{i, j+1}^{n}-P_{i, j}^{n}}{\Delta y^{2}}+\frac{-P_{i, j}^{n+1 / 2}+P_{i, j-1}^{n+1 / 2}}{\Delta y^{2}}, \\
\frac{P_{i, j}^{n+1}-P_{i, j}^{n+1 / 2}}{0.5 \Delta t}=\frac{P_{i+1, j}^{n+1}-P_{i, j}^{n+1}}{\Delta x^{2}}+\frac{-P_{i, j}^{n+1 / 2}+P_{i-1, j}^{n+1 / 2}}{\Delta x^{2}}+ \\
+\frac{P_{i, j+1}^{n+1}-P_{i, j}^{n+1}}{\Delta y^{2}}+\frac{-P_{i, j}^{n+1 / 2}+P_{i, j-1}^{n+1 / 2}}{\Delta y^{2}} .
\end{gathered}
$$

The calculation is over if the following condition is fulfilled:

$$
\left|P_{i j}^{n+1}-P_{i j}^{n}\right| \leq \varepsilon
$$

where $\varepsilon$ is a small number; $n$ is iteration number.

If field of $P$ is computed we can calculate velocity components as follows

$$
u_{i j}=\frac{P_{i j}-P_{i-1, j}}{\Delta x}, v_{i j}=\frac{P_{i j}-P_{i, j-1}}{\Delta y} .
$$


For numerical integration of (2) we used four steps difference scheme of splitting [9]. For formation of the geometrical form of the computational domain "markers" (porosity technique) are used. This approach allows to create quickly geometrical form of the computational domain $[9,10]$.

\section{Results}

We consider T-shaped region with brattice (Figure 1). Direction of air flow is shown with arrows. Three scenarios are considered. The first scenario is ventilation of dead-end mine working with line brattice. The second scenario is a ventilation process of dead-end mine working with long line brattice. The third scenario is a ventilation process of dead-end mine working with line brattice and equipment. At time $t=0$ a uniform dust concentration is set $C_{0}=100$ (in dimensionless form) in dead-end mine working.

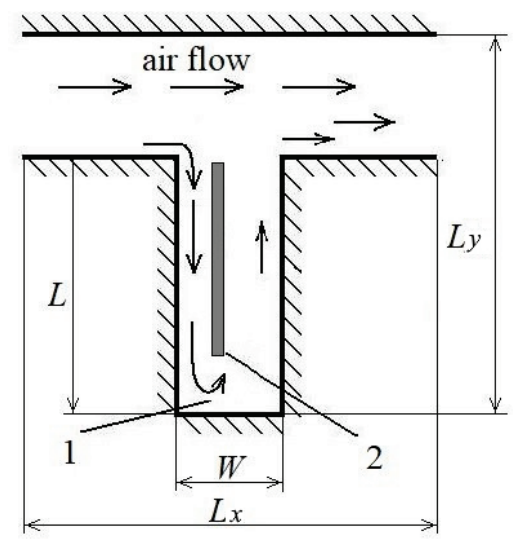

Fig. 1. Scheme of computation domain: 1 - dead-end mine working; 2 - brattice; $L$ - the dimensionless length of the dead-end mine working; $W$-the dimensionless width of the dead-end mine; $L_{x}$ - the length of the computational domain; $L_{y}$-the width of the computational domain.

In Figures $2-4$ contamination zones for $t=15$ are presented. All parameters (time, length, concentration) are dimensionless.

Dust concentration changes in the region during ventilation and it can be seen in Figure 5. Concentration (dimensionless) which is shown in Figure 5 is computed for receptor position which is shown in Figure 4. Results are presented for scenario \#1 and scenario \#2.

From Figure 5 it can be seen that the process of concentration decrease takes part very slowly. In Figure 6 change of concentration vs time is shown for scenario \#3.

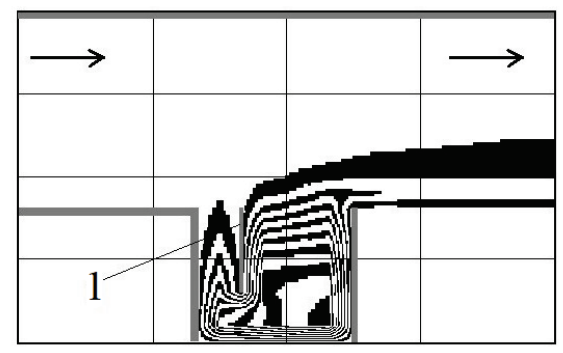

Fig. 2. Distribution of dust concentration, $t=15: 1$ - brattice. 


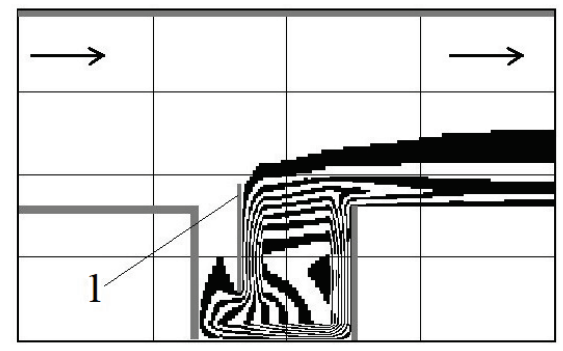

Fig. 3. Distribution of dust concentration, $t=15: 1-$ brattice.

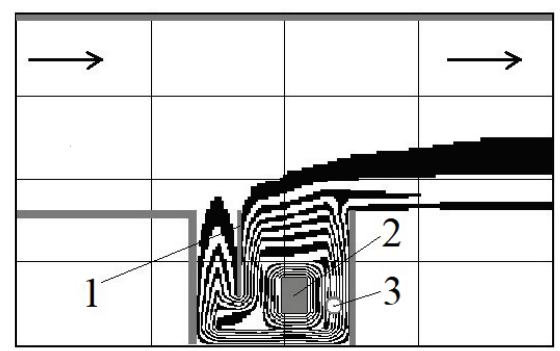

Fig. 4. Distribution of dust concentration, $t=15: 1$ - brattice; 2 - equipment; 3 - receptor position.

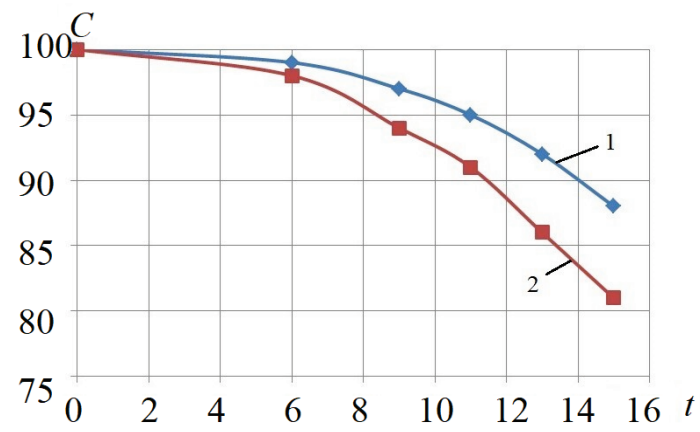

Fig. 5. Maximum dust concentration in computational domain: 1 - scenario \#1;2 - scenario \#2.

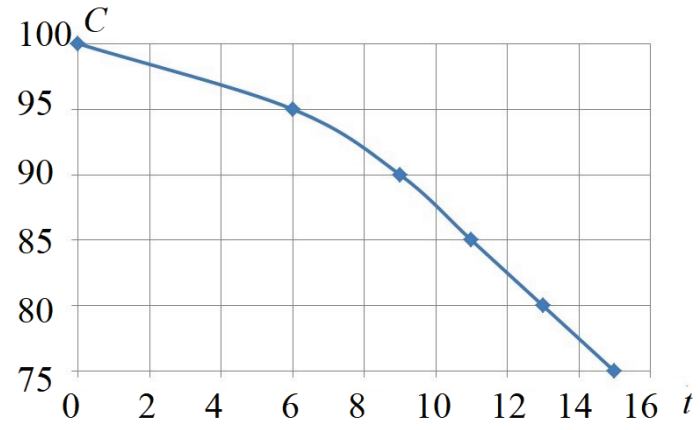

Fig. 6. Dust concentration in computational domain.

Worthy of note that it takes 10 seconds to compute the problem. So, presented results show that developed model can be used for pilot calculations of dust dispersion in dead-end mine workings. 


\section{Conclusions}

Briefly, we have presented quick computing CFD model to analyze the process of dead-end mine working ventilation. We have studied the contamination zones in dead mine with line brattice. Such regions have complex flow pattern and this creates significant difficulties for mathematical modeling. Fluid dynamics problem is solved using model of potential flow. That allows to compute quickly velocity field in the computational domain having complex geometrical form.

At present, in Ukraine, there is an evident deficit of mathematical models to perform CFD modeling of dust dispersion in mines. The developed model allows to study multifactorial process of dust dispersion using not powerfull computers.

\section{References}

1. Kalabin, G.V., Baklanov, A.A., Amosov, P.V. (1990). Method of dead-end mine working aerodynamics calculation on the base of mathematical modeling. Phizikotehnichesskiye problem razrabotki poleznykh iskopayemykh, 1, 74-88

2. Kremenchutskiy, N.F., Mukha, O.A, Stolbchenko, Ye.V. (2011). Calculation of deadend mine working ventilation with usage of differential equations. Naukovii visnyk natsionalnogo girnychogo universytetu, 2, 136-139

3. Feroze T., Genc B. A CFD model to evaluate variables of line brattice ventilation system in empty heading. The Journal of the Southen African Institute of Mining and Metalurgy, 117 (2017)

4. Aminossadati, S.M., Hooman, K. (2008). Numerical simulation of ventilation air flow in underground mine workings. In: North American Mine Ventilation Symposium

5. Kurnia, J.C., Sasmito, A.P., Mujumdar, A.S. (2014). CFD Simulation of Methane Dispersion and Innovative Methane Management in Underground Mining Faces. Applied Mathematical Modelling

6. S. Aminossadati, K. Hooma. Numerical simulation of ventilation air flow in underground mine workings. Retrieved from; https://www.researchgate.net/ publication/43494851_Numerical_simulation_of_ventilation_air_flow_in_underground mine_workings

7. Loytszyanskii, L.G. (2003). Mechanics of liquid and gas. Moscow: Drofa

8. Biliaieva, V.V., Kirichenko, P.S., Gunko, E.Yu., Bondarenko, I.O., Mashykhina, P.B., Yakubovska, Z.M. (2019). Computer simulation of dead-end mine working ventilation. Science and Transport Progress, 5 (83), 16-25

9. Zhurovskii, M.Z., Skopetskii, V.V., Khrysch, V.K., Biliaiev, M.M. (1997). Numerical modeling of pollutant dispersion in environment. Kyiv: Naukova dumka.

10. Biliaiev, M.M., Rusakova, T.I., Kolesnik, V.Ye., Pavlichenko, A.V. (2017). Determination of Areas of Atmospheric Air Pollution by Sulfur Oxide Emissions from Mining and Metallurgical and Energy Generating Enterprises. Naukovii visnyk natsionalnogo girnychogo universytetu, 3, 100-106

11. Marchuk, G.I. (1982). Mathematical modeling in problem of environment. Moskva: Nauka

12. Samarskii, A.A. (1983). Theory of differential schemes. Moskva: Nauka 